\title{
The Rapid Spread of Covid-19 Pandemic and Its Psychosocial and Economic Challenges on Motorcycle Riders in the Transport Industry in Kimili Subcounty, Bungoma County, Kenya
}

\author{
Kato Masika Erastus \\ Masinde Muliro University of Science and Technology, \\ P.O. Box 190-50100, Kakamega, Kenya \\ *Corresponding author details: Kato Masika Erastus; erastusmasika@gmail.com
}

\begin{abstract}
The spread of Covid-19 pandemic in East Africa has greatly undermined the daily economic activities of the motorbike operators in the region during its first phase. The motor bike riders (boda boda) have been condemned for the fast spread of Covid-19 due to the nature of their business of moving people from place to place and deep into communities. Boda boda transport system has been embraced by most people in East Africa since it is fast, flexible and cheap and has become more popular among the poor segments of the society. However, with the outbreak of Covid-19 pandemic the East African governments have put spotlight on the motorbike transport industry as a weak link in the fight against the Covid-19 pandemic. In Uganda for instance President Yoweri Museveni had to ban boda boda operators from carrying passengers for the fear of community-to-community spread of the pandemic. The consequences of the negative perception against the boda boda operators carried psychosocial as well as economic repercussions with it such as intense fear, obsessive behaviour, anxiety and stigma. The purpose of this study was to investigate Covid-19 pandemic and its psychosocial as well as economic challenges on the motorbike transport in Kimilili Sub County, Bungoma County, Kenya. The study population comprised of all the motorcycle riders within Kimilili town. The sample size comprised of 24 motor bike riders sampled from the 12 main town stages from which 2 participants were selected through simple random sampling. The study adopted qualitative research design where descriptive survey was employed. The study employed Focused group Discussion (FGD) tool for data collection. The FGD involved the participants in a discussion on common psychosocial problems affecting the boda boda operators. Data was collected and analyzed qualitatively then presented in prose. The results revealed that motorbike riders had faced numerous challenges ranging from reduced income and stigma to police harassment and corruption. The study recommends reforms that can restore sanity and dignity to the boda boda public transport industry such as financial empowerment, social protection, training of staff and counselling services.
\end{abstract}

Keywords: covid-19 pandemic; psychosocial; economic; challenges

\section{INTRODUCTION}

Psychosocial is a term derived from the combination of psychological and social behavioural conditions such as family problems, anxiety, anger and aggression to others. It examines the relationship between person's fears and how that person relates to others (Psychosocial Dictionary, 2012). Economic challenges relate to income, employment, and cost of living. With the outbreak of the Covid-19 pandemic in Kenya numerous psychosocial as well as economic challenges have affected the lives of many people especially the poor in society. Although these challenges have been in existence for a long time, Covid-19 pandemic has intensified the situation and made them more severe on the ground. The boda boda industry is one of the sectors immensely affected by the Covid-19 economically as well as psychosocially. The shutdown of schools and lockdown of the country's major commercial cities greatly undermined the performance of the boda boda sector as this had reduced their income twofold. The boda boda is the most common mode of transport among teachers and students where some had contracts lasting a month end from which they a earned a salary; but now with schools under Locke and key they have no regular and reliable earning.
The fear of being put in quarantine, police arrests, and heavy court fines for flouting the rules instilled a lot of fear among the boda boda operators leading to low daily income. The failure to pay up bike loans has equally caused a lot of stress among the riders whose bikes have been impounded by the loaning companies. This study adopted qualitative research design where descriptive survey was employed. The study employed Focused group Discussion (FGD) involving 24 boda boda operators to participate in a discussion on specified themes. Data was collected and analyzed qualitatively through verbatim and presented in prose. The results revealed that motorbike riders had faced numerous challenges ranging from reduced income and stigma to police harassment and corruption. The study recommends reforms that could restore sanity and dignity to the boda boda public transport industry such as financial empowerment, training of staff, counselling services and social protection.

\section{BACKGROUND TO THE STUDY}

Following the much spotlight shade to the boda boda public transport in relation to the spread of the Covid-19 in East Africa, the boda boda operators have consequently 
been subjected to economic as well as psychosocial difficulties because they are perceived as a weak link to the spread of the pandemic (Irandu, 2020). Quite a number of them have suffered stigma as a result of the negative perception by the public when they realize they are highly targeted in the mitigation campaigns against the spread of Covid-19. The boda boda have lost considerable income with only a few passengers willing to use bikes in the initial phase of the spread of the pandemic. According to Moraa (2013), most of the boda boda bikes belong to rich people in the area who hire the poor unemployed youth mostly their relatives as riders. At the end of the day the earnings belong to the bike owners as per the agreement between the parties involved. Normally they pay an agreed amount of money every day to the bike owners ranging from USD 3 to 4 per day and any extra money earned by the operator is considered his/her day's wages.

In hard economic times the riders sometimes fail to raise the agreed amount to the bike owners and as a result they face the threats of withdrawal of contract by the bike owners thus causing immense anxiety to them. Those servicing motorbike loans end up being frustrated as they fail to service their loans. The outbreak of Covid-19 made the situation worse as most of them were unable to raise the daily amount due to tough anti-corona prevention measures that targeted the boda boda riders, coupled with curfew hours commencing from $7 \mathrm{pm}$ in the evening to 5 am in the morning in Kenya which are considered peak hours for boda boda business. The boda bodas have decreed poor business as a serious consequence of Covid19 pandemic. Meeting the conditions set by the ministry of health and that of transport and communication for safety against the spread of Covid-19 pandemic was a nightmare to most of them.

The National Crime Research Centre (NCRC Report No.14 of 2018) identified several psychosocial as well as economic challenges that face the boda boda transport industry. The report cited culture of impunity, family breakdown due to high rate of infidelity, substance abuse, and school dropout and mob justice. The report blamed the weak law enforcement system, substance abuse and high rate of illiteracy which have affected the psychological wellbeing of the riders. The report also named police operations as a weak link in the enforcement of the transport rules where they are involved in bribery to compromise the law and contribute to the culture of impunity among the boda boda riders. Fear of victimization by authorities has intensified the culture of impunity among the boda boda according to the report.

Intense fear can lead to frustration, anxiety and destructive anger among the victims. The use of fear appeals to fight Covid-19 pandemic had positive results according to a study by Kinya (2020) in which the researcher investigated on the efficacy of fear appeals on adoption of Covid-19 preventive measures. The fear for 14-day quarantine, heavy court fines, police arrests, the negative public perception and fear for contracting Covid-19 pandemic among the boda boda operators were deterrent to social health risk behaviour but had psychological repercussions to reckon with. According to Bates (2014), use of fear appeals is a motivator of the successful enforcement of health behavioural change among people. However, such threats of intense fear have negative consequences on the mental health of the target group despite enhancing behaviour change. The behavioural change may not be sustainable in the long run. The arbitrary arrests of the boda boda operators by the police and locking them up in police cells without giving a hearing and an understanding approach to their problems may cause acute anger that can destroy life among the operators.
According to BBC News (3rd July, 2020), Hussein Walugembe, a 29-year-old boda boda taxi rider in Uganda set himself ablaze over police bribe after they had impounded on his motorbike. His attempts to recover the bike were futile causing him a state of intense frustration and burnout. He ends his life by setting himself ablaze. The president of Uganda Yoweri Museveni apologized to the family of the deceased and asked police responsible for the death to be arrested as investigations commenced. The underlying cause for the young man's death was social psychological and the police should have read and interpreted the symptoms to save a life.

The much spotlight shade to the boda boda industry with regard to the spread of Covid-19 pandemic has also stigmatised them. According to Ndung'u (Sunday $28^{\text {th }} 2020$ ), over 400 boda bodas on Thika road rejected their profiling as Covid-19 pandemic carriers which has immensely stigmatized them. This led to fewer passengers opting to use motobike transport as they secured alternative means of transport. This was not the case before in the early phase of the lockdown where the boda boda enjoyed monopoly in the transport sector and recorded a booming business (Sitole, June 28 $8^{\text {th }}$ 2020). The strict observance of the Covid-19 pandemic rules for safety was meant to bring change in behaviour by over indulging obsessively in ideal behaviour to fight the spread of Covid-19 pandemic. Such behavioural practice may lead to obsessive compulsive disorders among the operators.

Souvik (2020) in his research on psychosocial challenges of Covid-19 pandemic found out that there were psychiatric manifestations of numerous psychosocial and economic challenges such as mass hysteria, economic burden, financial losses, mass fear of corona phobia. Older people and the marginalized were more vulnerable to infection of Covid-19

\section{STATEMENT OF THE PROBLEM}

Use of intense fear appeals by the ministry of health and that of transport and communication against the boda boda for behavioural change and for compliance to the laid down regulations may have been effective in the short-term, but in the long term may result in social psychological repercussions such as intense fear, frustration, anger and anxiety. It is therefore critical for the ministry of healthy to use fear appeals with caution not to cause mental health conditions among the boda boda riders.

\section{OBJECTIVE OF THE STUDY}

The specific objective of the study was to investigate Covid19 pandemic and its economic and psychosocial challenges among motor bike operators in the public transport industry in kimilili sub county, Bungoma County.

\section{RESEARCH QUESTION}

What are economic and psychosocial challenges of Covid-19 pandemic among the motorbike riders (boda boda) in kimilili sub county, Bungoma county Kenya?

\section{Methodology}

This study adopted qualitative research design where descriptive survey was employed. The target population of the study were all the motorbike riders in Kimilili town who offer transport services to the public. The sample size was 24 respondents selected through simple random sampling from 12 boda boda stage points. Two respondents were purposively selected from each stage point. A simple FGD schedule was developed for data collection. The sampled respondents were involved in a discussion on various themes of the study which were analyzed in verbatim and presented in prose. 
Target Population and Sample Size

The target population of this study were all the motorbike riders in Kimilili town offering public transport service in town at 12 stage points. Two respondents were purposively selected from each stage giving a sample size of 24 respondents to form an FGD team as illustrated in table 1.

\section{Sample Matrix}

TABLE 1: Sample Matrix

\begin{tabular}{|c|c|}
\hline Main motor bike stage points & Sample size \\
\hline DCs place stage & 2 \\
\hline Kaptola junction stage & 2 \\
\hline Hospital gate stage & 2 \\
\hline Riziki supermarket stage & 2 \\
\hline Kapsokwony junction stage & 2 \\
\hline Kitale $\mathrm{T}$ - junction stage & 2 \\
\hline Misikhu line junction & 2 \\
\hline Coop bank stage & 2 \\
\hline Main bus terminus stage & 2 \\
\hline Bokoli junction & 2 \\
\hline Total & 24 \\
\hline
\end{tabular}

Source: Field Data

\section{RESULTS AND DISCUSSIONS}

Response rate and demographic background of the respondents.

The respondents were aged between 20 and 50 years and were all males. Most of those who were young were former school leavers and school drop outs both at primary and secondary school level. Most of the respondents relied on the motorbikes for the livelihood.
The elderly ones were also peasant farmers with families that relied on them. All respondents participated in the study and responded to the simple FGD themes successfully. Therefore, the response rate was $100 \%$.

The study sought to investigate Covid-19 pandemic and its economic and psychosocial challenges among the boda boda riders in Kimilili Sub County. The responses on various questions were discussed and the results were tabulated and presented in table 2 .

TABLE 2: Responses on Economic and Psychosocial Challenges among the Boda boda operators.

\begin{tabular}{|c|c|}
\hline FGD Theme & Description of verbatim responses \\
\hline $\begin{array}{l}\text { Status of bike loan repayment during the } \\
\text { Covid-19 pandemic }\end{array}$ & $\begin{array}{l}\text { The results show that } 10(40 \%) \text { of the boda boda operators had } \\
\text { problems with the servicing of their motorbike loans due to low daily } \\
\text { income. They stated 'it is difficult to repay the motorbike loans in the } \\
\text { Covid-19 pandemic period' }\end{array}$ \\
\hline Responses on police arrests and harassment & $\begin{array}{l}17(70 \%) \text { of the respondents discussed and agreed that police arrests } \\
\text { and harassments were on the increase. They reported: police acts of } \\
\text { arresting and harassment of boda boda operators have yielded a lot fear } \\
\text { among most of us' }\end{array}$ \\
\hline $\begin{array}{l}\text { Responses on daily earning during the } \\
\text { Covid- } 19 \text { pandemic }\end{array}$ & $\begin{array}{l}7(30 \%) \text { of the respondents opined that daily earnings had dropped } \\
\text { drastically: 'there are very few passengers travelling; thus, very little } \\
\text { income as we try to cope up with compliance with the ministry of health } \\
\text { guidelines.' }\end{array}$ \\
\hline Fear for contracting Covid-19 pandemic & $\begin{array}{l}12(50 \%) \text { of the respondents discussed and unanimously agreed that } \\
\text { they feared contracting Covid-19. 'I fear contracting Covid-19 because } \\
\text { boda boda is a risk-taking business as one of us can contract it easily'. }\end{array}$ \\
\hline $\begin{array}{l}\text { Stigmatisation of boda boda during Covid-19 } \\
\text { pandemic }\end{array}$ & $\begin{array}{l}11(45 \%) \text { of the respondents agreed that there was mild stigma and } \\
\text { stated: 'passengers who avoided using motorbikes allege that boda boda } \\
\text { operators are conduits of the spread of Covid-19'. }\end{array}$ \\
\hline Responses on intense fear and anxiety & $\begin{array}{l}16(65 \%) \text { of the respondents supported the fact that there was fear and } \\
\text { anxiety among the boda boda operators and stated: 'I have fear and } \\
\text { anxiety of contracting Covid-19 due to my interaction with strangers every } \\
\text { day.' }\end{array}$ \\
\hline Responses on fear for medical check ups & $\begin{array}{l}19(80 \%) \text { of the respondents supported the fact that majority of the boda } \\
\text { boda operators were not ready for Covid-19 testing and checkups for } \\
\text { fear of Covid- } 19 \text { positive results. They stated: "I'm not ready for Covid- } \\
19 \text { testing and checkups." }\end{array}$ \\
\hline
\end{tabular}

Source: Survey Data (2020) 
Table 2 indicates responses on various sub themes of the qualitative data analysis. Responses on the status of motorbike loan repayment among the boda boda operators reveal that $40 \%$ of the boda boda operators had problems with the servicing of their motorbike loans. This was due to low daily income as a result of curfew and lockdown measures by the government. They stated: 'It is difficult to repay motorbike loans in the Covid-19 pandemic period. This implies that boda boda operators who operated loan motorbikes suffered great economic hardships as they were unable to repay their loans. Mr. Isaac Yatima a middle aged boda boda rider at Kahindi Bata shop stage in Kimilili town said, "It is very difficult for me to raise enough money from motorcycle transport business to be able to service my loan for 2 motorbikes and save little for the family. I surrendered the 2 motorbikes to the company. It is better if one operated his own bike free of loan". Mr. Yatima was supposed to raise USD 20 for each of the motorcycle weekly. Erick wanjala another boda boda rider from the same stage point said, "Since schools were closed our income has dropped by half. I could not raise enough money for the owner of the motorcycle. He withdrew the motorcycle and kept it in his house." Mr. Wanjala was therefore waiting for corona to disappear before he could embark on bike riding business. The two examples of views by the boda boda riders, indicate a difficult economic situation for the boda boda riders who depended on bikes for livelihood. This finding on bike loans repayment is also supported by Daily Nation (24th July, 2020) which reported that boda boda business was adversely hit by the Covid-19 pandemic.

On police arrests and harassment, the respondents discussed where $70 \%$ of them reported that police arrests and harassments were on the increase during the corona pandemic due to the much spotlight shade on boda boda operators. They reported: "Police acts of arrest and harassment of boda boda operators have brought fear among us. Police vehicles are often seen carrying impounded bikes whose riders flouted the law. Police also demand for bribes ranging from USD 5 to 10 or threaten locking up riders in cells," commented Joseph Nangabo a boda boda in Kimilili.

Use of fear appeals was therefore used by the police but with a wrong motive of exploiting the riders as they demanded for bribes. The fear of police arrests made the operators flout the laws by speeding away from police to escape the arrests. "The consequences of being arrested by police were the fear of being forced into quarantine for 14 days, police bribes and heavy court fines," added Mr. Nangabo. This finding is supported by Kinya (2020) in his article about efficacy of fear appears on adoption of Covid19 preventive measures. This boda boda culture of impunity is perpetrated by the weak law enforcement system, substance abuse and high level of illiteracy among the operators (NCRC Report, 2018). The BBC News (3 ${ }^{\text {rd }}$ July 2020) also reported a case of police cruelty that drove a boda boda rider in Uganda into a state of burnout after he had failed to recover his impounded motorcycle from the police and ended his life by setting himself ablaze.

The theme on 'daily earning during the Covid-19 pandemic' was discussed where $30 \%$ of the respondents opined that daily earnings had dropped drastically: 'There are very few passengers travelling thus very little income as a result of the compliance with the ministry of health guidelines. This implies that the lockdown and curfew rules undermined the performance of boda boda business. The finding is supported by Namu (April, 18 ${ }^{\text {th }}, 2020$ ) who reported of a difficult season of making decision among the boda bodas whether to eat or heal from the pandemic due to decimal performance of the economy with barely enough income to sustain families during the lockdown. Serious lockdown of the nations should be accompanied by financial as well as psychosocial support given to the people by the government of the day.

The theme of 'Fear for contradicting Covid-19 pandemic' was discussed, and $50 \%$ of the respondents unanimously confirmed that they had feared contracting Covid-19. ' I fear contracting Covid-19 because boda boda is a risk-taking business as one can contract it easily'. Since it was believed that boda boda riders were potential agents of the spread of Covid-19, there was fear among most of them for contracting the disease. Most of the boda boda, due to their culture of impunity had continued to flout the laws thus increasing chances of contracting and spreading the disease (Ministry of Health Thur. April 9th, 2020). Souvik (2020) also named intense fear as one of the psychosocial effects of Covid-19 in his research on the psychosocial effects of Covid-19. This situation may be resolved through provision of information to the victims and awareness rather than threatening warning to the operators.

The theme on 'stigmatisation of boda boda during Covid19 pandemic' was discussed and $45 \%$ of the respondents agreed that there was mild stigma and stated: 'Passengers who avoided using motorbikes allege that boda boda operators are conduits of the spread of Covid-19. This assumption has hence led to the stigmatization of the boda boda operators. This finding is in agreement with Ndung'u (Sunday 28 ${ }^{\text {th }}, 2020$ ) who reported that over 400 Thika road boda boda operators were facing stigma of being seen as carriers of Covid-19 from the public as their former customers seek new means of transport amid Covid-19 pandemic. The boda bodas rejected their profiling as Covid-19 carriers and demanded for fairer treatment. The findings concur with souvik (2020) who found that there were numerous psychosocial effects of Covid-19 on society such as stigmatization. Stigma can lead to depression as a result of rejection. This should therefore be avoided through responsible acts and through talk therapies.

The theme of the presence of anxiety was discussed where $65 \%$ of the respondents supported the fact that there was fear and anxiety among the boda boda operators and stated: I have fear and anxiety of contracting Covid-19 due to my interaction with strangers every day. "The respondents admitted that they carry passengers from all backgrounds and they do not discriminate whom to carry and whom not to carry. The chances of contracting the diseases through motorcycle transport were high hence the anxiety. Most of them did not have protective clothes to shield themselves from coming into body contact with their passengers during the riding. The fear among boda boda to contract Covid-19 if they were forced into quarantine was highly attributed by frequent reports that quarantine places were for infection of the pandemic (Souvick, 2020).

On the fear for medical checkups and Covid-19 testing, 80 $\%$ of the respondents supported the idea that majority of the boda boda operators were not ready for Covid-19 testing for fear of turning positive to Covid-19. They stated: "I'm not ready for Covid-19 testing". The respondents agreed that testing was good for them but they were not willing to take the initiative to go for testing unless it was made mandatory. This could be due to the unpreparedness for the potential outcomes from testing such as being put quarantine for 14 days, stigma from their peers, anxiety and the possibility of the occurrence of death. These challenges can be mitigated by availing critical information and psychosocial support programs to encourage voluntary testing at government cost. 


\section{SUMMARY AND CONCLUSION}

The study objective was to investigate covid-19 pandemic and its psychosocial and economic challenges among the boda boda operators in Kimilili Subcounty, Bungoma county Kenya. The results indicate mild manifestations of psychiatric conditions such as, stigma, frustration, fear and anxiety, economic burden, police harassment and arrests.

\section{RECOMMENDATIONS}

The study makes the following recommendations:

i) On the Status of bike loan repayment, the government should cushion the boda boda financial burden through provision of flexible credit advances to boda boda operators during the Covid-19 pandemic.

ii) Strict police surveillance and discipline to fight impunity among the boda boda operators.

iii) Availing of psychosocial support and counselling services among the bodaboda operators

iv) Lastly the boda boda operators should be encouraged to join savings in the credit SACCOs to be able to sustain themselves during hard economic times.

\section{REFERENCES}

[1] Bates, M. E. (2014). Fear as Motivator of Health Campaigns. An Examination of Fear Appeals Massaging and Skin Cancer Prevention (A Master's Thesis, Clemson University). Retrieved at https://www.pdfs.semanticscholar.org/1a2d/3c183 39b57afe2d1ddcfozddbf531ba2b12.pdf.

[2] BBC News (3rd july 2020). Uganda Boda Boda Rider Sets Himself on Fire Over Bribe. Retrieved at https://www.bbc.co.uk>news>topics

[3] Irandu, M.E. (2020). Transportation in Kenya, The Weak Link in the Fight of Covid-19: Nairobi. Retrieved at https://uonresearch.org.>blog>transport.
[4] Kinya,K.K. (2020). Efficacy of Fear Appeals on Adoption of Covid Preventive Measures: A Case of Boda Boda Riders in Nairobi County, Kenya. International Journal of Research

[5] GRANTHAALAYAH 8(6) 219- 228. Retrieved at https://doi.org/029121/granthaalyah.u8:2020.1533.

[6] Moraa, G. \& Nyachieo, M. (2013). Creating Employment through Transport: The Youth and Motorcycle (Boda boda) in Kitengela, Kajiado County Kenya. Research Journal in Organizational Psychology \& Education Studies 2(4) 154-157

[7] Namu. J. A. (April 18th 2020). Covid-19 in Africa: To Eat or to Heal? Retrieved from https://www.theelephant.info>2020-07-24

[8] National Crime Research Centre report. (2018). Boda boda Motorcycle Transport and Security Challenges in Kenya. Nairobi: Jomo Kenyatta Foundation.

[9] National Crime Research Centre report. (2018). Boda boda Motorcycle Transport and Security Challenges in Kenya. Nairobi: Jomo Kenyatta Foundation.

[10] Ndung'u, M. (Sunday 28 th June, 2020). Boda boda Riders: Stop Seeing Us Carriers of Covid-19. Retrieved at https:// www.pd.co.ke.>country>news.

[11] Psychosocial Definition (Psychosocial Dictionary, 2012). Retrieved at https://www.your. dictionary.com>psy

[12] Sitole, D. (18th June, 2020). Business is booming for Kenya's. Retrieved from https://www.citymetric.com>transport

[13] Souvik, D. etal. (2020). Psychosocial Impact of Covid19. Retrieved from https://www.covid19.who.int/coronavirus/worlddashboard. 